\title{
Rediscovery of the Cherry-throated Tanager Nemosia rourei in southern Espírito Santo, Brazil
}

\author{
CLAUDIA BAUER, JOSÉ FERNANDO PACHECO,ANA CRISTINA \\ VENTURINI and BRET M. WHITNEY
}

\section{Summary}

We report the rediscovery of the Cherry-throated Tanager Nemosia rourei in southern Espírito Santo, Brazil, in February 1998, and the first substantive observations of its behaviour, vocalizations and other aspects of its natural history. Approximately 10 individuals, occasionally in groups of up to five birds, were located in humid montane forest at $1,100 \mathrm{~m}$ a.s.l. at the privately owned "Fazenda Pindobas IV" $\left(20^{\circ} 19^{\prime} \mathrm{S}, 41^{\circ} 17^{\prime} \mathrm{W}\right)$. This small population appears to be safe, as the property owners are preserving the remaining native forest there, and hope soon to register the land as a Private Natural Heritage Reserve (RPPN). The species probably also occurs at similar elevations on neighbouring fazendas. Past reports of the species are reviewed, and the accuracy of the type locality, "Muriaé, Minas Gerais" is re-evaluated. As a result, we suggest that our locality of rediscovery, Jatibocas, where Helmut Sick surely saw a group of eight birds in August 1941, and the Nova Lombardia (= Augusto Ruschi) Biological Reserve, where a single individual was certainly sighted by Derek Scott and others in October 1995, all in south-central Espírito Santo, be considered the only confirmed points of occurrence of the Cherry-throated Tanager.

São relatadas a redescoberta da Saíra-apunhalada (Nemosia rourei) no sul do Espírito Santo, Brasil, em fevereiro de 1998, e as primeiras observações substanciais de seu comportamento, vocalizações e outros aspectos de sua história natural. Aproximadamente dez indivíduos (ocasionalmente em grupos de até 5 aves) foram localizados em floresta úmida montana em $1.100 \mathrm{~m}$ de altitude na propriedade particular Fazenda Pindobas IV $\left(20^{\circ} 19^{\prime} \mathrm{S}, 41^{\circ} 17^{\prime} \mathrm{W}\right)$. A pequena população ora localizada parece estar em segurança, considerando que os proprietários vem preservando os remanescentes de floresta nativa local e esperam em breve transformá-los em Reserva Particular do Patrimônio Natural (RPPN). A espécie provavelmente ocorre, pelo menos, nas fazendas vizinhas em ambientes e altitudes similares. Relatos anteriores da espécie são revisados e a exatidão da localidade tipo "Muriaé, Minas Gerais" é reavaliada. É sugerido que apenas três localidades, todas na região centro-sul do Espírito Santo, sejam consideradas como pontos de ocorrência confirmados de Nemosia rourei: Fazenda Pindobas IV, local da redescoberta aqui relatada; Jatibocas, onde Helmut Sick certamente viu um grupo de oito indivíduos em 1941 e a Reserva Biológica de Nova Lombardia (Augusto Ruschi), onde um único exemplar foi, em última análise, certamente observado por Derek Scott e outros, em outubro de 1995.

\section{Introduction}

The Cherry-throated Tanager was described in the second half of the nineteenth century from a single specimen sent from Brazil to the Zoological Museum of 
Berlin (Museum für Naturkunde der Humboldt-Universität zu Berlin, MNHB) by the naturalist Carl Euler (Cabanis 1870). Carl Hieronymus Euler (1832-1901) was a regular collaborator of the museum, sending specimens and publishing in the Journal für Ornithologie the results of his fieldwork (mostly observations of the nesting habits of birds) at "Fazenda Bom Valle", in the interior of Rio de Janeiro near the Minas Gerais border. In the case of the Cherry-throated Tanager, Euler sent a letter with the specimen, explaining that it had been collected by Mr. Jean de Roure at "Muriahié ... situated on the left, therefore north bank of the Rio Parahyba do Sul". He added that in more than 30 years of collecting, he had not met with the species before, an early testimony of the singular rarity of the Cherry-throated Tanager.

Two years after publication of the type description, Nemosia rourei was illustrated in a black-and-white plate in the Journal für Ornithologie (vol. 20, tab. figure 1). The original of this plate was in colour, and would have been stored in Frankfurt (J. Steinbach to Helmut Sick in litt. November 1973).

Emilie Snethlage (1868-1929), who worked at the Museu Nacional do Rio de Janeiro (MNRJ) during the 1920s, was the first person to take an interest in finding Nemosia rourei in the wild. She visited two fazendas ("Barra Alegre" and "Nova Aurora") near Muriaé in November and December 1926, judging by specimens of other birds she collected and deposited at the MNRJ. In Ornithogische Monatsberichte 35:96 (1927) Stresemann wrote (free translation by J. Haffer): “Dr Emilia Snethlage attempted in vain to find the beautiful Nemosia rourei Cabanis at the terra typica; she wrote to the editor [Stresemann] that a mounted pair of this species exists in the Museu Nacional in Rio de Janeiro, presumably from Espírito Santo. Until now only the type specimen was known ..." Curiously, this report by Snethlage of the existence of two additional specimens was forgotten by Stresemann (1954) himself, who years later affirmed that the Berlin type was unique! Additional evidence of the past existence of these specimens at the MNRJ is in a list (Anonymous 1876) of birds and mammals deposited in that institution, in which Nemosia rourii (sic) is represented. Judging by the date of publication of this list, these (or this) specimens (the list does not state the numbers of each species) could even be older than the type specimen, and could have been collected by Jean de Roure himself, or contemporaries. Among the pre-eminent zoologists of the MNRJ at that time was Carl Schreiner (1841-1896), quite probably the author of the anonymous list, who was in close contact with Carl Euler, frequently collecting at his fazenda near Cantagalo (Snethlage and Schreiner 1929). The two specimens mentioned above apparently had disappeared from the MNRJ by 1940, since they did not figure in an inventory of the bird collection made by Adolph Schneider (A. Schneider, unpubl. report; see Pacheco and Bauer 1995). Consequently, everything published on the Cherrythroated Tanager in recent decades has considered that only one specimen (the type: MNHB No. 20326, sexed as adult male) has been taken.

In the past 20 years, it has been presumed that Nemosia rourei "must be close to extinction, if it still exists" (King 1979) or "there seems little hope that this distinctive, presumably forest, species could still be extant" (Scott and Brooke 1985). The high degree of deforestation and the significant amount of ornithological coverage in south-eastern Brazil, together with the lack of records during the past 50 years, led Collar et al. (1992, 1994) to again judge the Cherry-throated 
Tanager "likely to be extinct". Most recently, Stattersfield et al. (1998) considered the "global status" of Cherry-throated Tanager as Critical, and cited it (clearly in error) as being known from "northern São Paulo".

\section{Records in this century}

On 8 August 1941, Helmut Sick observed "a band of eight Calospiza (= Tangara) with red throats" at Jatibocas, Espírito Santo, $900 \mathrm{~m}$ a.s.l. He was not able to collect a specimen, but he objectively noted in his field catalogue details of the plumage, and that the tanagers were not associated with any other birds. At that time, just two years after his arrival in Brazil, Sick was not surprised by novelties in the field. Nemosia rourei was omitted from Pinto's (1944) Catálogo das Aves do Brasil as well as his (1952) compilation of birds of Minas Gerais, but was included by Meyer de Schauensee (1966), which may explain Sick's delay in publishing his important observation. In 1976, Sick visited the MNHB and examined the type of Nemosia rourei, and realized that this was the species he had seen at Jatibocas 35 years earlier.

The first recent report of the survival of the Cherry-throated Tanager came five years ago, when the bird artist Eduardo P. Brettas told Luiz P. Gonzaga of a bird he had seen briefly a few weeks before. This observation took place on 17 July 1994 at the privately owned "Fazenda Pedra Bonita", north of Pirapetinga $\left(21^{\circ} 36^{\prime} \mathrm{S}, 42^{\circ} 23^{\prime} \mathrm{W}\right)$, at about $150 \mathrm{~m}$ elevation in eastern Minas Gerais. The bird, seen in a flock where individuals of Hooded Tanager Nemosia pileata were present, had a black mask, black wings and tail and a red patch on the throat extending to the upper breast, the rest of the underparts being white. Brettas thought initially that the bird could be a cardinal Paroaria sp., but in the library he found that his sketch of the bird matched closely the colour plate of Nemosia rourei in Sick (1993), and became confident that this was in fact the species he had seen (E. P. Brettas in litt. to L. P. Gonzaga 1994). Following this report, Gonzaga and Larissa Schmauder T. da Cunha spent a week, from 16 to 22 August 1994, at Fazenda Pedra Bonita watching bird flocks in search of the Cherrythroated Tanager, but only Hooded Tanagers were recorded. Other surveys that failed to locate the species at this locality were undertaken by Gonzaga and Pacheco on 15-16 June 1995, and Brettas and Luis F. Silveira on 26-27 July 1996. In the absence of documentation or confirmation of Bretta's record by a second observer, it was decided not to publicize it. Moreover, the $\mathrm{O}^{\prime}$ Neill illustration in Sick (1993), which was not based on examination of the type specimen ( $\mathrm{O}^{\prime} \mathrm{Neill}$ pers. comm. to B.M.W.), and Brettas's field sketch, while nearly identical, do not depict the correct and very distinctive (clearly visible in the field; see below) distribution of black on the face of Nemosia rourei.

More recently, Scott (1997) reported that on 5 October 1995 he and others observed an unusual tanager foraging with a mixed-species flock of tanagers and other small birds in the forest canopy, at Nova Lombardia (= Augusto Ruschi) Biological Reserve in central Espírito Santo. The bird was observed only briefly, but sufficient detail was seen to suggest to the observers that it was a Cherrythroated Tanager. They noted, however, a discrepancy in the observed pattern of red on the throat/breast with that shown in published colour illustrations (Isler and Isler 1987, Sick 1993). Despite a close match to the illustrations in sev- 
eral other important respects, this led Scott (1997) to suggest the possibility that they had seen an intergeneric hybrid tanager, with "likely parents" being Hooded Tanager Nemosia pileata and Rufous-headed Tanager Hemithraupis ruficapilla, and that a hybrid origin for this individual would indicate the possibility that the type specimen and the eight birds seen by Sick in 1941 also were hybrids. Scott (1997) was not the first to suggest that the Cherry-throated Tanager could be a hybrid. For reasons unexplained, Sibley (1996) stated that Nemosia rourei is "probably a hybrid." We have even become aware (L. F. Silveira pers. comm. 1998), that in recent years certain Brazilian ornithologists have been working under the hypothesis that the type specimen is an artifact, composed of parts of Paroaria sp. and other species. The putative hybrid and artifactual origins of the Cherry-throated Tanager are both clearly unfounded, as shown by our rediscovery of the species in the field, related below.

\section{The rediscovery}

In October 1996, Bauer and Pacheco initiated an inventory of the avifauna of various localities in southern Espírito Santo. This programme was an integral aspect of Bauer's MSc dissertation, which focused on distribution patterns of birds in this, one of the least-known sectors of the Atlantic Forest. During the last (and seventh) of the planned study visits, on 22 February 1998, at about oghoo C.B. emphatically called attention to a bird overhead in a mixed-species flock which she immediately identified as Nemosia rourei. C.B. and the other researchers present, J.F.P., A.C.V., Pedro Rogério de Paz, Mariana Pacheco Rehen, and Luciano Petronetto do Carmo were able to follow at least three individuals for about 20 minutes before the flock moved away. This took place at "Fazenda Pindobas IV" ( $\left.20^{\circ} 19^{\prime} \mathrm{S}, 41^{\circ} 17^{\prime} \mathrm{W}\right)$, Municipality of Conceição do Castelo, in the montane region of southern Espírito Santo, at approximately 1,100 $\mathrm{m}$ a.s.1. (Figure 1). The particular forest fragment (about 100 ha in size) where the sighting occurred is called "Mata da Pingadeira". The exciting news was published immediately (Bauer et al. 1998, Pacheco 1998).

Realizing the necessity of documenting the sighting, the same observers returned to the Mata da Pingadeira on the morning of 24 February, and relocated the mixed-species flock containing, on this occasion, four Nemosia rourei. Other flock members included Brassy-breasted Tanager Tangara desmaresti, Giltedged Tanager Tangara cyanoventris, Golden-chevroned Tanager Thraupis ornata, Azure-shouldered Tanager Thraupis cyanoptera, Blue Dacnis Dacnis cayana, Rufous-headed Tanager Hemithraupis ruficapilla, Blackpoll Warbler Dendroica cf. striata, Streaked Xenops Xenops rutilans, Rough-legged Tyrannulet Phyllomyias burmeisteri, Blue-naped Chlorophonia Chlorophonia cyanea, Brown Tanager Orchesticus abeillei, Scaled Woodcreeper Lepidocolaptes squamatus, Yellow-eared Woodpecker Veniliornis maculifrons, Chestnut-bellied Euphonia Euphonia pectoralis, Chestnut-crowned Becard Pachyramphus castaneus, Sharpbill Oxyruncus cristatus and Rufous-browed Peppershrike Cyclarhis gujanensis, apparently led by Sirystes Sirystes sibilator. Playback of a recording of call notes of one of the Cherry-throated Tanagers made on a Sony TCM-5000 cassette recorder permitted us to attract the birds repeatedly, and make observations of plumage, soft part colours, and behaviour over a period of about 1.5 hours. At the same time, sev- 


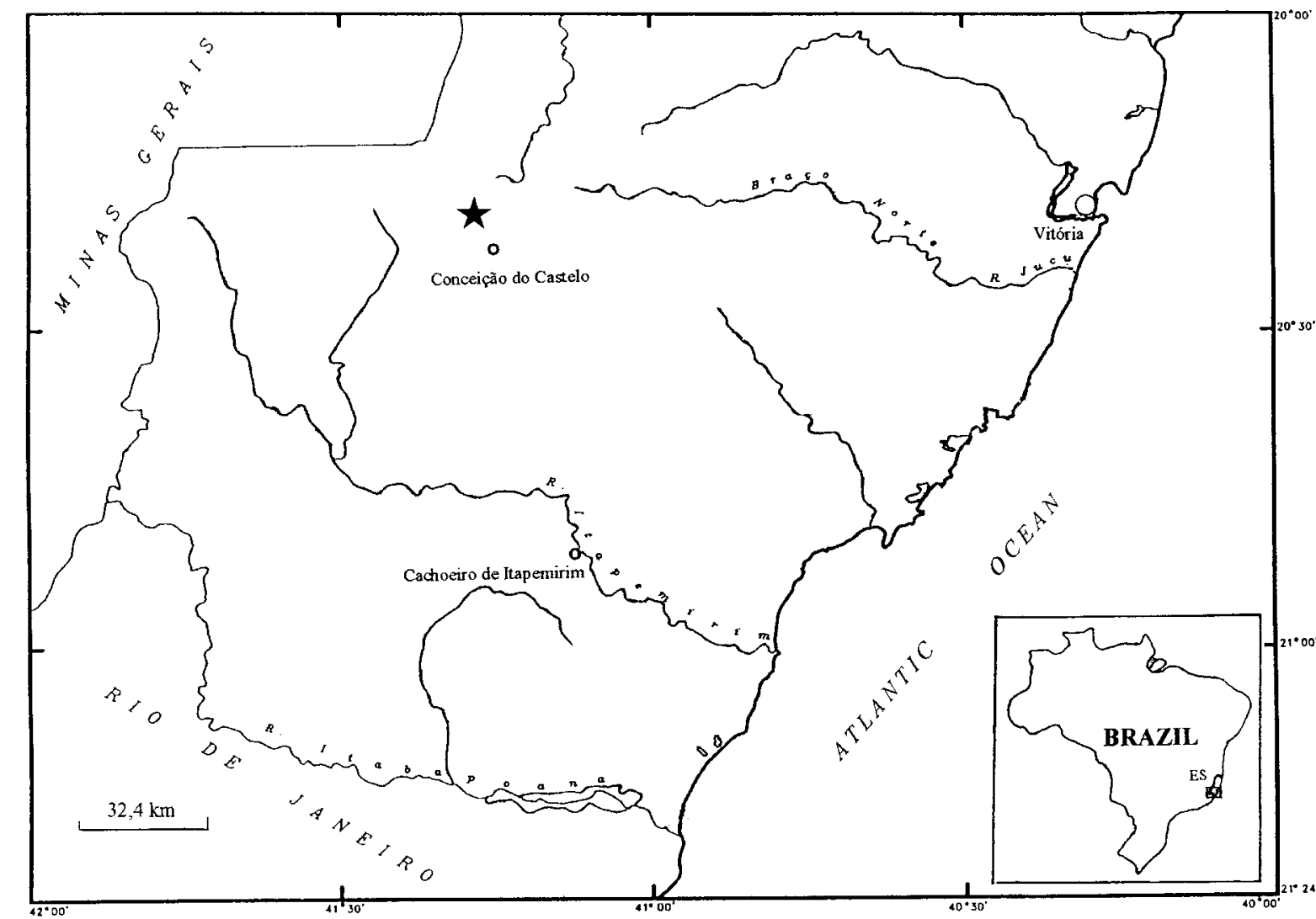


eral photographs of the birds were made by Pedro R. da Paz and Pacheco with a Canon EOS $500 \mathrm{~N}$ and a Vivitar $100-300 \mathrm{~mm}$ zoom lens.

\section{Description}

All of the approximately 10 individuals observed in this account (see Additional Remarks) were closely similar in size, proportions and plumage, and matched Cabanis's (1870) original description well. The wing is actually not entirely black, at least the inner three remiges (secondaries or tertials) being conspicuously bicoloured, entirely black on the proximal web, and mostly greyish-white on the distal web. This greyish-white area is widest anteriorly, narrowing to a welldefined margin near the tip and ending abruptly at the feather shaft. The grey scapular feathers often overlay a section of the black upperwing coverts, creating the effect of a grey panel in this region. The folded wingtip reaches slightly less than half the length of the tail, and falls just short of the tip of the uppertail coverts. The tail is essentially not graduated and square-tipped. The irides of all individuals appeared to be yellow or orange-yellow, the tarsi and feet pink, and the bill black. Soft part colours have not been described for Nemosia rourei, although the original description states that the feet were pale, and Scott (1997) noted that the probable Cherry-throated Tanager they saw had a conspicuously pale iris.

A slight amount of variation in the shape and extent of red on the throat and upper breast was noted among the individuals. Thus, some birds showed a wider throat/breast patch with a well-defined point (posterior extension) into the upper breast, while others displayed a somewhat thinner and less distinctly pointed patch, sometimes with irregular edges. Beyond these minor but absolute variations, we also noted that the apparent shape of the patch on any given individual varied with the viewing angle, such that a side view frequently produced the illusion that the red was limited to the throat, and cut squarely at the bottom edge (just as described by Scott (1997)). On at least two occasions, we observed individuals having a dull brownish (even yellowish-brown) cast to the throat patch, with no or only a hint of red. These birds were always in the company of birds with bright-red throats, and could have been immatures.

The sides of the face and head were marked with a nearly continuous and crisply defined black band from the forehead to the nape, interrupted slightly in the centre of the nape, a detail which was difficult to perceive in the field. This black band contrasted strongly with the pale grey crown and red throat, and also served to set off the yellow iris. We noted a slight variation in the width of the black band crossing the forehead, but we do not know whether this is individually variable, or might be correlated with sex or age. The extensive black head band was illustrated quite accurately by Morton Isler (Isler and Isler 1987), but was shown as a short, rounded mask terminating just behind the eyes by $\mathrm{O}^{\prime} \mathrm{Neill}$ (Sick 1993, 1997). The field sketch by E. Brettas sent to L. P. Gonzaga (mentioned above) showed a facial pattern like that of the $\mathrm{O}^{\prime}$ Neill figure.

In the February 1998 sightings involving Cherry-throated Tanagers, attracted repeatedly with tape playback, we observed a conspicuous white spot that appeared to be at the tip of the outermost rectrix (clearly visible in Fig. 2, and was especially obvious when the birds spread their tails. However, this was not 


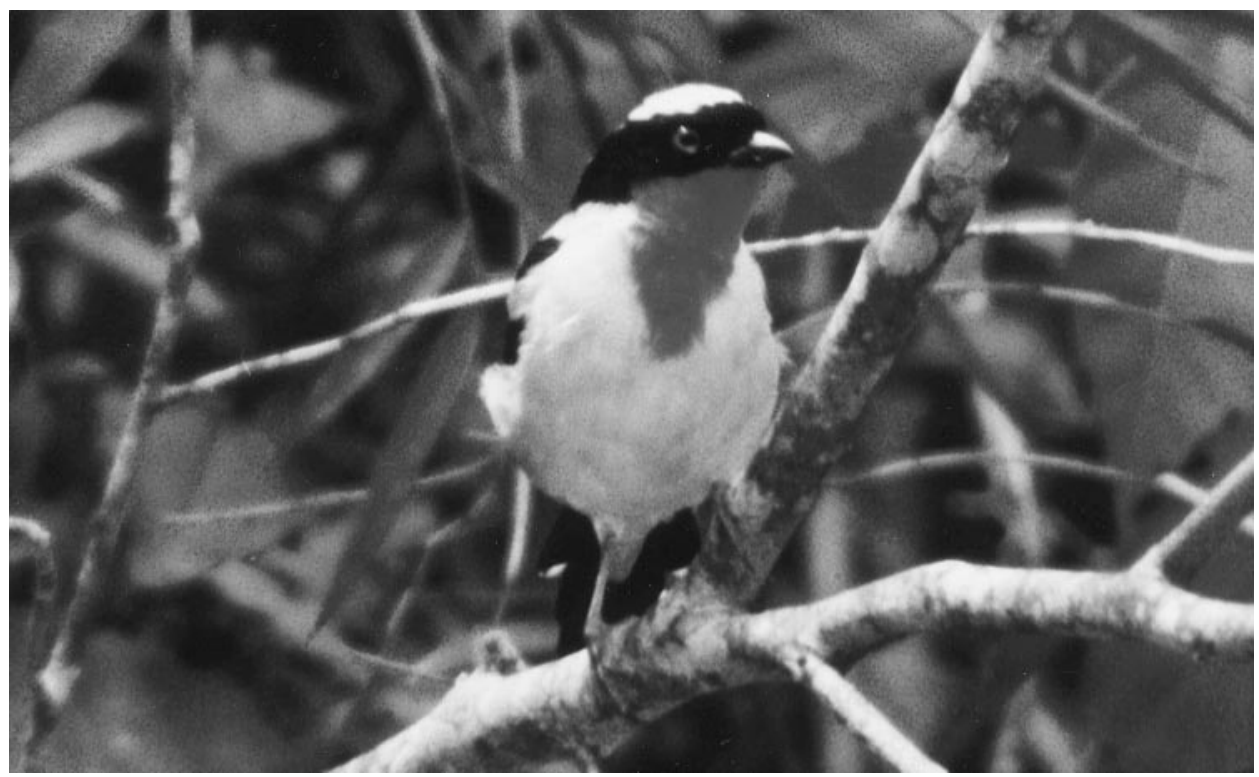

Figure 2 . Cherry-throated Tanager Nemosia rourei (J. F. Pacheco).

mentioned in the original description, and Jürgen Fiebig of MNHB (in litt. 15 June 1998), who kindly examined the type specimen and sent photographs to us, confirmed that the outer rectrices bear no white spots. This ambiguity was resolved on 4 September 1998, when G. D. A. Castiglioni, M. P. Rehen and A.C.V. captured a Cherry-throated Tanager in a mist-net at Fazenda Pindobas, and determined that the rectrices were indeed unmarked black, and that the white tips were on the uppertail coverts. The capability of stiffly spreading the uppertail coverts in the manner shown in the photograph, and the fact that they are conspicuously white-tipped, may come into play in some intra- or interspecific interactions, but in any event, it impressed us as quite unusual among tanagers.

The degree of contrast between the grey upperparts and the crown appears to vary significantly with the lighting circumstances, such that the crown (especially just posterior to the black forehead) frequently looks nearly white in the field (Figure 2), although it is actually grey with a whitish margin. Another subtle detail of plumage that we noted in the field was a small black patch on the posterior portion of the thighs.

The individual captured in a mist-net on 4 September 1998 was ringed on the left tarsus with a metal band and on the right with two coloured bands, black above light blue. Some measurements obtained with a caliper were: total length $12.5 \mathrm{~cm}$, culmen (from skull) $9.0 \mathrm{~mm}$, bill depth $5.5 \mathrm{~mm}$, bill width $5.0 \mathrm{~mm}$, body mass $22 \mathrm{~g}$.

\section{Voice and Behaviour}

The voice of the Cherry-throated Tanager is sharp and far-carrying. The most common vocalization is a group of $2-5$ clear (no or only weak harmonic or modulated components) notes delivered in about $0.3-1.0 \mathrm{~s}$, the first two or three of 
which peaking at and having greatest amplitude at about 5-6 kHz, often followed by a terminal pair of higher notes, at about $8 \mathrm{kHz}$. The first two notes, which are frequently given alone while foraging, are of about $0.2-0.3 \mathrm{~s}$ duration, and separated by intervals of approximately 0.1 s. If a third note is given, it may be like the first two but perhaps more often it is slightly shorter and lower in frequency and may or may not have a loosely modulated quality. The notes forming the terminal pair, in addition to being at higher frequency, are also shorter, with durations less than half those of the initial notes, and are delivered slightly more closely together than are the initial notes. All notes ascend abruptly at the beginning then descend throughout their (brief) duration, for an overall drop (peak to lowest point) of approximately $0.5 \mathrm{kHz}$. Variations of this vocalization are repeated frequently but at irregular intervals by all members of a group, usually at least several seconds apart during undisturbed foraging. A typical example of this vocalization is shown in Figure 3A. Another frequently heard vocalization is more complex, and less regular in structure, but is composed of notes like the ones described above interspersed with tightly spaced series of shorter notes (Figure 3B). It may be a type of song, as it seems to be given mostly by the most aggressive member of a group, especially following repeated tape-recording playback.

Almost all foraging was accomplished with near-perch reaches and gleans, mostly in the interior of tall tree crowns (sometimes fairly low to the ground in edge trees). Birds hopped and hitched with rapid sideways movements of one leg followed by the other along branches, frequently stopping to investigate the sides and undersides of branches with look-under searches typical of some other tanager genera (terminology follows Remsen and Robinson 1990). We noted virtually no hangs from limbs or foliage, although birds often spent several seconds clambering in thick bunches of twigs and leaves. They frequently shifted the orientation of the head and body to the substrate as they moved along branches, scanning continuously for arthropod prey. Prey items captured included two small (less than $3 \mathrm{~cm}$ ) caterpillars, at least one large ant in a tree crown, and several small, unidentified arthropods. A bird fed one of the caterpillars to its (presumed) mate, which was the only other conspecific in the area at the time. We did not observe Cherry-throated Tanagers foraging for fruit, although fruits of various sizes were available in several species of trees in the area, attracting a number of other kinds of birds. During tape playback, a presumed male once adopted a distinctive, probably aggressive, posture in which the head and neck were extended roughly parallel to the ground in the direction of the tape recorder, and the wings were laterally spread about halfway and held in position for about $2 \mathrm{~s}$. Birds sometimes descended briefly to less than $2 \mathrm{~m}$ above the ground in response to tape playback.

\section{Status and Conservation}

The Cherry-throated Tanagers at Fazenda Pindobas IV have been observed there during the months of February, April, June, July, August, September, October and late November. Thus, the preliminary conclusion is that the species does not perform altitudinal migrations, although more years of data should be compiled before this can be stated with certainty. 


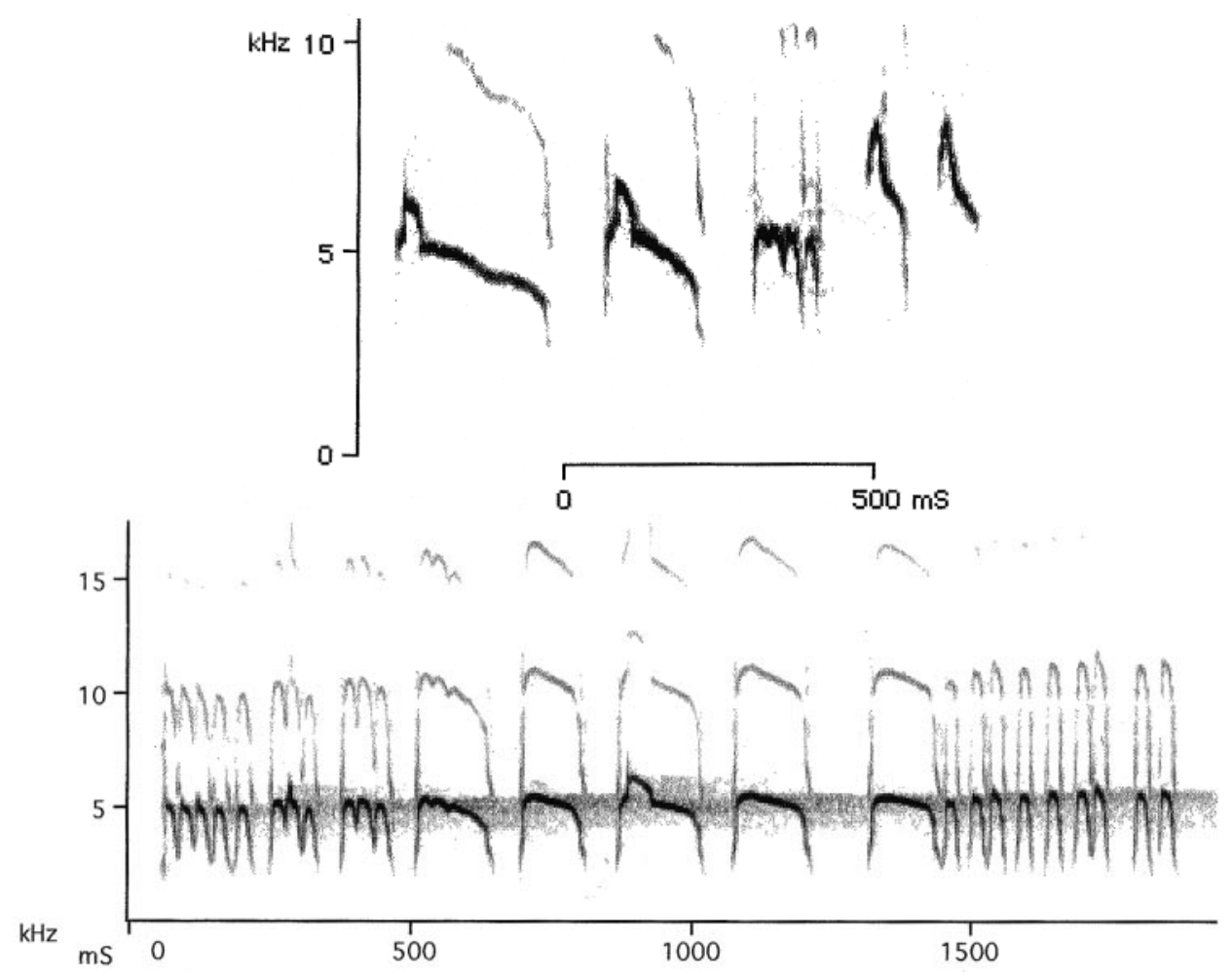

Figure 3A,B. Principal vocalizations of the Cherry-throated Tanager Nemosia rourei recorded at "Fazenda Pindobas IV", Espírito Santo, Brazil. See text for more detailed descriptions. Vocalizations were recorded after tape playback, but are substantially like natural vocalizations. A. Common "call" delivered frequently while foraging, often comprising only the first two notes. Recorded 24 February 1998 by J. F. Pacheco (ASEC JFP 183A). B. More complex, "song-like" vocalization. Recorded by L. P. Gonzaga I August 1998 (ASEC LPG 122/6). Spectrograms produced with Canary 1.2.1 of the Bioacoustics Program of the Cornell Laboratory of Ornithology, Ithaca, New York, U.S.A. Filter Bandwidth $533 \mathrm{~Hz}$, Window Function Blackman, sound digitized at 44.1 Hz, 16-bit.

On 22 October 1998, the ringed individual was seen by the authors in the same forest fragment about $200 \mathrm{~m}$ from the capture site. This bird was the most responsive of a group of five to tape playback. Two days earlier, in a different area of the fazenda, we were able to determine that another group of five Cherrythroated Tanagers contained no ringed birds. It therefore seems probable that at least two groups of five birds each survive at Fazenda Pindobas IV.

Fazenda Pindobas IV comprises 3,167 ha, 943 of which are in native forest scattered in 51 fragments. One of the largest forest areas is the "Pingadeira Complex" in which we have found the two groups of Nemosia rourei. This complex of several loosely connected fragments is continuous with forest on neighbouring properties. These montane forests are situated between roughly 1050 and 1160 $\mathrm{m}$ a.s.l., and are considered transitional between the dense and open (with many palms) rainforest classes of Ururahy et al. (1983). The principal economic activity of the fazenda is cultivation of Pinus elliotti and Pinus patula for industrial use. 
The owners of Fazenda Pindobas IV, Mr Camilo Cola and Mrs Ignez Massad Colla, are now aware and proud of having the Cherry-throated Tanagers on their property, and plan to protect all remaining forest fragments on the fazenda in the hope that they can register it as a Private Natural Heritage Reserve (RPPN).

Given what we now know of the historic and current records of occurrence of the Cherry-throated Tanager, how can we identify priority areas for learning more about it? One natural suggestion would be to return to the type locality, just as Snethlage did unsuccessfully in 1926. Cabanis's (1870) original description designated no province (today, state), but gave the collecting locality as on the left, or north bank of the Rio Paraíba do Sul, which runs for most of its length in the state of Rio de Janeiro. This, and the fact that Carl Euler (who sent the specimen with a letter to Cabanis in Berlin) was well known for his work in the Cantagalo region of Rio de Janeiro, led to many years of confusion of the type locality being in Rio de Janeiro state. Sick (1979) was the first author to correctly locate "Muriahié" (= Muriaé) in Minas Gerais, and, as summarized in Collar et al. (1992, p. 897), the type locality of the Cherry-throated Tanager is currently understood to be "Muriaé, Minas Gerais". However, several considerations, when taken together, lead us to question whether this locality unambiguously refers to the present city of Muriaé.

Euler (1869) mentioned that his friend Jean de Roure maintained a collection of birds, that he sold examples from it to museums in Europe, and that de Roure had worked for more than 30 years in the mountains around Nova Friburgo, specifically in the upper Rio Macaé (= Macaé de Cima area today). There seems to be no written evidence that Jean de Roure worked anywhere else, aside from his collection of Nemosia rourei at "Muriahié". This seems anomalous to us, and we suggest that the possibility of de Roure obtaining the specimen of Nemosia rourei from another collector or seller and recognizing that it was quite unusual should be considered. Additionally, the similarity of "Muriahié" to the only known locality of de Roure's activities, "Macahé" (as it was spelled in the late nineteenth century), suggests some potential for confusion. Considering that Cabanis (1870) transcribed the locality information for the species description from Euler's letter, who must have transcribed it from the hand of de Roure, the possibility of an error by one of the parties involved should not be discarded. Finally, the above points may take on greater significance when one considers that the city of Muriaé, Minas Gerais, is at about 210 m elevation, and situated in a region of predominantly semi-deciduous forest, in both respects considerably different from the three confirmed or virtually certain localities (Fazenda Pindobas IV, Jatibocas and Nova Lombardia) for the Cherry-throated Tanager in south-central Espírito Santo. Although it seems plausible that the Cherrythroated Tanager could perform altitudinal migrations or other wanderings that at least occasionally extend as low as Muriaé, current evidence suggests that this is not the case. Thus, Muriaé is probably not a regular area of occurrence for Nemosia rourei, and we suggest that its validity as the type locality remains open to further inquiry. Could it be that the Cherry-throated Tanager will one day be found in the montane forests of the Macaé de Cima region? The general Nova Friburgo area has been worked by numerous ornithological collectors, mostly in the nineteenth century. Nonetheless, if Jean de Roure truly did collect the type 
specimen, we think it is possible that he obtained it in the Macaé de Cima area (for additional discussion of this controversial origin, see Pacheco 1999).

The way is now clear for further documentation of the distribution and status of the Cherry-throated Tanager. Formal surveys and even birdwatching excursions in the montane regions of southern Espírito Santo and nearby Minas Gerais and Rio de Janeiro, concentrated in the narrow 900-1200 m elevation belt, have the potential to bring to light important new data on this extraordinary bird.

\section{Acknowledgements}

The owners, Mr Camilo Cola and Mrs Ignez Massad Colla, managers Luciano Sales and Antônio Décio, and various staff members of Fazenda Pindobas IV (Itapemirim Corporation) greatly aided our research on the Cherry-throated Tanagers, for which we are very grateful. We also wish to acknowledge especially our colleagues Pedro Rogério de Paz, Mariana Pacheco Rehen and Luciano P. do Carmo for many days of valuable assistence in the field. We thank L. P. Gonzaga for contributing his excellent recordings of Cherry-throated Tanager and producing the sonagram figures; G. D. A. Castiglioni for assistance in capturing and ringing the Cherry-throated Tanager; and Luis Fábio Silveira for information on the "artifact" theory of origin of the type specimen. Special thanks to J. Haffer for help with the literature search and contact with staff at MNHB, and J. Fiebig of MNHB for making photographs of and commenting on the type specimen for us.

\section{References}

Anonymous (1876) Computo geral das collecções zoologicas existentes no Museu Nacional. Arch. Mus. Nacional, Rio de Janeiro 1: 101-132.

Bauer, C., Pacheco, J. F., Venturini, A. C., Paz, P. R. de, Rehen, M. P. and Carmo, L. P. do (1998) O primeiro registro documentado do séc. XX da saíra-apunhalada, Nemosia rourei Cabanis, 1870, uma espécie enigmática do sudeste do Brasil. Atualidades Orn. 82: 6.

Cabanis, J. (1870) Ueber neue brasilische Nemosie oder Wald-Tangare, Nemosia Rourei nov spec. J. Orn. 18: 459-46o.

Collar, N. J., Gonzaga, L. P., Krabbe, N., Madroño Nieto, A., Naranjo, L. G., Parker III, T. A. and Wege, D. C. (1992) Threatened birds of the America: the ICBP/IUCN Red Data Book. Cambridge, U.K.: International Council for Bird Preservation.

Collar, N. J., Crosby, M. J. and Stattersfield, A. J. (1994) Birds to watch 2. the world list of threatened birds. Cambridge, U.K.: BirdLife International (Conserv. Series 4).

Euler, C. (1869) Beiträge zur Naturgeschichte der Vögel Brasiliens. J. Orn. 17: 241-255.

Isler, M. L. and Isler, P. R. (1987) The tanagers: natural history, distribution and identification. Washington, D.C.: Smithsonian Institution Press.

King, W. B. (1979) Red Data Book, 2. Aves. Second Edition. Morges, Switzerland: International Union for Conservation of Nature and Natural Resources.

Meyer de Schauensee, R. (1966) The species of birds of South America and their distribution. Narberth: Livingston.

Pacheco, J. F. (1998) Cherry-throated Tanager Nemosia rourei rediscovered. Cotinga 9: 41.

Pacheco, J. F. (1999) É de Minas Gerais o exemplar único e original de Nemosia rourei? Atualidades Orn. 89: 7.

Pacheco, J. F. and Bauer, C. (1995) Adolf Schneider (1881-1946): Alguns dados sobre a 
vida e obra do chefe da expedição de 1939 do Museu de Ciências Naturais de Berlim que trouxe Helmut Sick para o Brasil. Atualidades Orn. 65: 10-13.

Pinto, O. M. O. (1944) Catálogo das aves do Brasil. 2a. Parte. São Paulo: Departamento de Zoologia, Secretaria de Agricultura, Indústria e Comércio.

Pinto, O. M. O. (1952) Súmula histórica e sistemática da ornitologia de Minas Gerais. Arq. Zool. São Paulo 8(1): 1-52.

Remsen, J. V, Jr and Robinson, S. K. (1990) A classification scheme for foraging behaviour of birds in terrestrial habitats. Pp. 144-160 in M. L. Morrison, C. J. Ralph, J. Verner and J. R. Jehl, eds. Avian foraging: theory, methodology, and applications. Stud. Avian Biol. 13 .

Scott, D. A. (1997) A possible re-sighting of the Cherry-throated Tanager Nemosia rourei in Espírito Santo, Brazil. Cotinga 7: 61-63.

Scott, D. A. and Brooke, M.de L. (1985) The endangered avifauna of south-eastern Brazil: a report on the BOU/WWF expeditions of 1980/81 and 1981/82. Pp. 115-139 in A. W. Diamond and T. E. Lovejoy, eds. Conservation of tropical forest birds. Cambridge, U.K.: International Council for Bird Preservation (Techn. Publ. 4).

Sibley, C. G. (1996) Birds of the world. Version 2.o. Naples, FL: Thayer Birding Software.

Sick, H. (1979) Notes on some Brazilian birds. Bull. Brit. Orn. Club. 99(4): 115-120.

Sick, H. (1993) Birds in Brazil, a natural history. Princeton: Princeton University Press.

Sick, H. (1997) Ornitologia Brasileira. Edição revista e ampliada por J. F. Pacheco. Rio de Janeiro: Nova Fronteira.

Snethlage, E. and C. Schreiner (1929) Beiträge zur Brasilianischen Oologie. Verh. VI Intern. Ornith. Kongr., Copenhagen, 1926: 576-640.

Stattersfield, A. J., Crosby, M. J., Long, A. J. and Wege, D. C. (1998) Endemic bird areas of the world. Cambridge, U.K.: BirdLife International (Conserv. Series 8).

Stresemann, E. (1954) Ausgestorbene und austerbende Vogelarten, vertreten im Zoologischen Museum zu Berlin. Mitt. Zool. Mus. Berlin 30: 38-53.

Ururahy, J. C. C., Collares, J. E. R., Santos, M. M. and Barreto, R. A. A. (1983) Vegetação, As regiões fitoecológicas, sua natureza e seus recursos econômicos. Estudo fitogeográfico. Pp. 553-623 in Projeto Radambrasil, Levantamento de Recursos Naturais, vol. 32. Rio de Janeiro: Ministério das Minas e Energia.

\section{CLAUDIA BAUER}

UFRJ, Laboratório de Ornitologia, Departamento de Zoologia, Instituto de Biologia-CCS, Cidade Universitária, Rio de Janeiro, 21944-970, Brazil.

\section{JOSÉ FERNANDO PACHECO}

UFRRJ, Instituto de Biologia, Lab. de Ornitologia, Rodovia BR465 Km 7, Seropédica, RJ, 23851970, Brazil.

\section{ANA CRISTINA VENTURINI}

Rua Francisco Corteletti, 333, Vila Velha, ES, 29111-070, Brazil.

BRET M. WHITNEY

Museum of Natural Science, 119 Foster Hall, Louisiana State University, Baton Rouge, Louisiana 70803, USA. 